\title{
Modeling the Professional Training of Future Teachers
}

\author{
Nurullaeva Shakhlo Uktamovna ${ }^{1}$,Aslanova Orzigul Pirimovna ${ }^{2}$, Yuldashev Sodik \\ Norchaevich ${ }^{3}$,Boymatova Munavvar Ravshan kizi ${ }^{4}$ \\ ${ }^{1}$ Associate Professor of Karshi State University, Candidate of Pedagogical Sciences \\ ${ }^{2}$ Doctor of Philosophy in Pedagogical Sciences of Karshi State University \\ ${ }^{3}$ Teacher of Karshi State University \\ ${ }^{4}$ Teacher of Karshi State University
}

\begin{abstract}
Annotation.
The pace of modern scientific and technological progress is such that all new types of activity are constantly introduce the everyday and industrial spheres of human life, for mastering which special training is needed. This is reflected in the discovery of new specialties in universities. Meanwhile, in order to receive special education at any level, it is first necessary to obtain a certain range of knowledge and skills of a general nature. The implementation of this function is carried out by a general education school, the main goal of which is through mastering the system of knowledge, skills and abilities laid down in the State Standard of General Secondary Education, to form and develop the personality of the student. Let us emphasize the fact that the means of personal development is the content of education. However, the modern secondary school follows the path of expanding curricula, when the names and programs of new disciplines appear, the amount of information in the old subjects increases, and the time allotted for their study, at best, remains the same, and at worst, decreases.

Key words: study, subjects increases, disciplines appear, modeling, adequate, simplicity, military, economic, sports, business games, knowledge, skills, abilities.
\end{abstract}

Article Received: 16th October, 2020; Article Revised: 30th December, 2020; Article Accepted: 08th January, 2021

All this leads to the fact that the lesson turns into a 40-minute monologue of the teacher, who tries to convey as much information as possible to students who do not pass into knowledge, since the process of interiorization is not provided. In turn, the transition of information from an external form to an internal one - the consciousness of a student - is possible only thanks to careful thought over and modeling of student activities by the teacher when designing the learning process in the classroom. Designing and modeling the educational process requires special competencies from the teacher. Modeling the professional training of future teachers also contributes to improving the quality of the workforce.

What is modeling?

The model basically means the system that is presented or realized and, displaying or reproducing the object of research, is able to replace it so that the study of this object gives us new information. In the philosophical literature, you can find other interpretations of the model, and there is a tendency to increase their number. In the broadest sense of the word, a model is any image, analogue (mental or conditional: an image, description, diagram, drawing, graph, plan, map, etc.) of an object, process or phenomenon (the "original" of the current model) used as its "deputy", "representative". The model captures the main components of the process (object, phenomenon, situation) and their connections in a schematic form, while helping to see the general picture, changes in its structural units and direct the attention of the researcher (or educator) to the search for dependencies between components, between this system and other systems.

Using the modeling method, we will be able to combine empirical and theoretical views in pedagogical research - to combine experiment, the construction of logical structures and scientific abstractions in the 
course of studying a pedagogical object.

While creating a model, the following features are needed to be considered:

1. Adequacy - the model must be suitable, similar to a real situation or an object that is a prototype or model.

2. Completeness - the model should reflect the original object in its completed form.

3. Simplicity - the model must reflect only the essential features of the object.

4. Completeness important material aspects of the object must be fully reflected in the model.

5. Probabilistic - reality should be expressed in the model approximately.

6. Mobility - The model should be easy to use even in different situations and situations.

7. Informativeness when creating a model, it is important to use all the information about the system.

8.

Scientific

conceptualization - when creating a model, you must first develop a scientific concept and build on it.

In the theory of pedagogical projecting, a predictive model is allocated for the optimal allocation of resources and the specification of goals; a conceptual model based on an information database and an action plan; an instrumental model that can be used to prepare execution tools and train teachers to work with pedagogical tools; monitoring model - to create feedback mechanisms and ways to correct possible deviations from the planned results; a reflective model, which is created to develop solutions in the event of unexpected and unforeseen situations (2).

1) micro - reduced models compared to the original;

2) adequate - the models are made in equal quantities with the original;

3) macro - models made in an enlarged size relative to the original.

\section{By appointment: \\ - a model for a}

scientific experiment - this type of model is used in the study of a model using various means of obtaining data about an object, the possibility of influencing the course of the process, in order to obtain new data about an object or phenomenon;

- a model for

integrated testing, this type of model is used for full-scale testing of a physical object and to obtain high reliability about its characteristics;

- optimization models are used to find the optimal indicators of the system (for example, finding the minimum costs or determining the maximum profit).

Models are also classified according to their application in different areas:

Educational: visual aids, educational programs, various simulators.

Experimental models are reduced or enlarged copies of the designed object. They are also called fullscale ones and are used to study an object and predict its future characteristics: a ship model is tested in a pool to determine the stability of the ship when rolling.

\section{Scientific}

and

technical models are created for the study of processes and phenomena: an electron accelerator, a device that simulates a lightning discharge, a stand for testing a TV.

Game: military, economic, sports, business games.

A strategic model not only reflects reality with varying degrees In of accuracy, but imitates it and assists to dels are devel point the strategy. The experiment is either repeated many times in order to study and evaluate the consequences of any actions on the real situation, or is carried out simultaneously with many other similar objects, but placed in different conditions. 
This method of choosing the right solution is called trial and error.

By way of presentation:

Material models can otherwise be called objective, physical. They reproduce the geometric and physical properties of the original and always have a real embodiment.

\section{Examples:}

1) Children's toys. From them, the child gets the first impression of the world around him. A two-year-old child plays with a teddy bear. When, years later, a child sees a real bear in the zoo, he will easily recognize it.

2) School aids, physical and chemical experiments. They simulate processes, such as the reaction between hydrogen and oxygen. This experience is accompanied by a deafening bang. The model confirms the consequences of the emergence of "explosive mixture" from harmless and widespread in nature substances.

3) Maps when studying history or geography, diagrams of the solar system and the starry sky in astronomy lessons and much more.

Material models implement a material (touch, smell, see, hear) approach to the study of an object, phenomenon or process.

Information models are a collection of information that characterizes the properties and states of an object, process, phenomenon, as well as its relationship with the outside world.

Information models cannot be touched or seen with one's own eyes, they have no material embodiment, because they are built only on information. This modeling method is based on an informational approach to studying the surrounding reality.

Information models do not exist in the real world. This is a set of information expressed in a certain way verbal (oral, written) or symbol.

Information

characterizing an object or process can have a different volume and form of presentation, and can be expressed by different means. This diversity is as limitless as the possibilities of each person and his fantasies are great. Information models include symbolic, computer and verbal (descriptive) models.

1) Symbolic model - an information model expressed by special signs, that is, by means of any formal language.

Symbolic models surround us everywhere. These are pictures, texts, graphics and diagrams.

Symbolic models may include mathematical models represented on the basis of mathematical formulas, geometric models consisting of graphic images, or models consisting of special symbols (e.g., chemical formulas, notes). ${ }^{1}$

2) Computer model - a model realized by means. This is the most modern model than other model types. Computer model - an IT tool consisting of two or three-dimensional images of various research objects in the virtual world, which has several conveniences in use.

3) Verbal (from the Latin "verbalis" - oral) model - an informational model in oral or written form.

These are models obtained as a result of deliberation, inferences. They can remain mental or be expressed verbally. An example of such a model can be algorithms of different samples. The researcher or programmer analyzes the situation and develops his own model of behavior. If the situation is modeled successfully, then the result will also be successful. These models include the idea that arose in the head of the inventor, the musical theme that flashed through the head of the composer, the rhyme that has sounded in the head of the poet so far. 
Symbolic and verbal models are usually interconnected. A mental image born in the human brain can be clothed in a symbolic form. And, on the contrary, the sign model helps to form the correct mental image in the mind.

An example of a verbal (descriptive) model is the "National Model for Personnel Training" of the Republic of Uzbekistan, which was formulated according to the program of the same name.

A research method based on the study and creation of a model of a real situation or object in order to determine its properties is called modeling. in the following stages:

Modeling is carried out modeling concept;

1) Development of the

2) determining the parameters of the model and creating the model;

3) conducting an experiment (in laboratory or natural conditions);

4) analysis of the results of experiments.

5) Use of the received data. of modeling in detail.

Let's discuss the stages

Modeling begins with collecting data about the problem, clearly defining the goals and objectives of the study. That is, the main goal of the study is determined and the scope of tasks to be completed is determined. Scientific basis of modeling - concept, hypothesis and criteria developed. The concept is the informational form of the model, so this stage is also recorded as an informational stage.

At the next stage, the parameters of the model are determined he transfer accuracy depends on a number of factors:

- the degree of accuracy of the object description in terms of the unambiguity of the results description; and the model is developed. At this stage, a layout is prepared based on the developed concept. When applying modern modeling techniques, the initial use of computer technology programs helps to demonstrate the principle of model accuracy.

The experimental stage of modeling is the main stage during which the developed model is tested in accordance with the research goal. During testing, care must be taken to ensure that the model is realistic.

At the next stage, the results of the experiment are analyzed. An important aspect of this phase is that in this phase, the data collected from the simulation is prepared using various other research methods - analysis, synthesis, comparison and mathematical statistical methods.

All data collected in the final stage is used for modification, forecasting or management. Based on the results obtained at this stage, it is possible to determine the effectiveness of the study. If the hypothesis established on the basis of the final conclusions during modeling is confirmed, then the model is adequate to the object. The degree of adequacy depends on the purpose and criteria of the modeling. And the simulation results can serve as a basis for predicting the behavior of the objects under study. It consists in the study of objects, systems, processes and phenomena based on their models.

At the stage of using the obtained data, the information obtained about the model is projected onto theory and practice in the form of new connections, factors, conditions, practical recommendations, organizational principles, etc. In this case, $\mathrm{t}$

- preparation of a qualitative model that allows solving the problem posed by the researcher;

- selection of optimal methods of model research; 
- literacy and accuracy of interpretation of the results obtained.

Modeling is a cyclical process. The researcher goes back to the very beginning, builds a model again, but more accurate.

In the philosophical dictionary, modeling is interpreted as the reproduction of the characteristics of a certain object on another object specially created on the day of its study, which is called a model (3).

Types of modeling by industry are classified by industry of human activity. For example, mathematical, biological, chemical, pedagogical, social, economic, historical, etc.

In the course of research through modeling, it will be possible to study physical objects (cars, airplanes, buildings, atoms); dynamic processes (evolution of humanity, pedagogical process, economic development); phenomena (tsunami, tornado); behavior of research objects.

The modeling method is used when building a model is indispensable. For example, the investigated object is very small or, conversely, large (molecules or landscape of the investigated geographic object) or the object no longer exists (mammoths, dinosaurs, primitive people).

And if during the experiments the original can be destroyed (for example, a building object), the model of the same object can be used in place of the original. The model can be used very successfully when a complex system is being investigated that has many features and interrelationships that need to be discarded for the purposes of study (training, pedagogical process).

The advantage of the modeling method is that in this process you can study the system as a whole or in parts. The researcher selects those parts that interest him, and discards the rest so as not to interfere. One object can have several models, each of which displays some of its features.(5)

The modeling method is very effective in the field of pedagogy, since the pedagogical process is a complex, systematic and cyclical process.

Pedagogical modeling is a reflection of the characteristics and criteria of the existing pedagogical system in a specially created experimental object called a pedagogical model. Moreover, in order to use some object as a model of another object, called in this case the original, it must meet the following conditions:

- the created model must be a system;

- have common criteria or parameters in some relation to the original;

- differ from the original in certain parameters;

- in certain respects, the model should replace the original during the research process;

- ensure research productivity.

In the article by N.A.Kozyrev and O.A.Kozyreva, the term "pedagogical modeling" is interpreted as follows: activities that provide the possibility of adaptive or acmeverified allocation of a certain component or their combination, for example, - study, research, detailing, systematization, classification, programming, adaptation, socialization, enlightenment, correction, self-education, self-realization, etc., allowing the teacher to determine the optimal mode of work within the framework of the goals and objectives, the allocated functions and principles, the accepted limitations and opportunities, the features of professional and pedagogical interaction and communication determined by the labor contract. (4).

The model in pedagogical research reflects the system of elements that reproduce the sides, connections, functions, conditions for the functioning of 
the pedagogical process. As A. M. Semenova writes, "A well-constructed model has an extremely attractive property: its study gives some new knowledge about the object - the original"(5). In this aspect, interpreting the above, the model of professional training of future teachers is needed in order to: learn to manage the process of training teachers and determine the optimal management methods under given conditions, goals and criteria; predict the direct and indirect consequences of the implementation of the given methods; based on pedagogical principles, to make the pedagogical process of professional training of future teachers technologically advanced.

To use pedagogical modeling as a method for studying the professional training of future teachers, the researcher must observe the following rules that increase the effectiveness of modeling:

- it is necessary to check the model for its compliance with the original;

- identify additional information about the model as a pedagogical system for the development of pedagogical science itself;

- pay attention to obtaining associated scientific results - the establishment of new connections, dependencies, the identification of pedagogical conditions and factors that affect the effectiveness of the model.

The information obtained concerns only the model and characterizes it, and not the pedagogical object selected at the stage of setting the problem. It is obvious that the constructed model has some independence, can exist and function outside the original, and therefore has its own properties, obeys its own laws. Therefore, based on its characteristics, the teacher chooses the appropriate research apparatus, which may not coincide with the original research apparatus. Abstraction from individual properties of the object under study, typical for modeling, allows using not only specific methods and techniques, but also changing the time distances of research, increasing the repetition rate, if necessary, etc. However, differences between the model and the original often lead to a distorted representation of the properties of the object of study, therefore, when studying the model, it is necessary to compare the new results with the available data about the original.

In pedagogical modeling, structural and functional models are most often in demand, in the construction of which an object is considered as an integral system, including its constituent parts, components, elements, subsystems. Parts of the system are linked by structural relations that describe subordination, logical and temporal sequence of solving individual problems.

Studying the structural and functional pedagogical model of the organization of preschool education at a university, Vikulina M.A. and Polovinkina V.V. determined the following main criteria for assessing the effectiveness of the model they developed:

- performance criterion: compliance with well-known standards of pedagogical interaction, information activities and pedagogical influence (indicators - growth or stabilization of positive manifestations on the part of students in educational interaction);

$$
\text { - criterion of }
$$

satisfaction of all subjects of the educational process (indicators - reviews and opinions of subjects of the educational process);

- the criterion of consistency and compliance with the principles of the development of a higherorder system, that is, the coordination of "orientation fields" of the development of the distance educational process and the university as a whole (indicators improvement of student performance 
indicators as evidence of improving the quality of education). (6).

The model of professional training of future teachers consists of the following components:

$$
\begin{aligned}
& \text { - personality; } \\
& \text { - the science; } \\
& \text { - society pedagogical }
\end{aligned}
$$

education;

$$
\begin{aligned}
& \text { - professional training. } \\
& \text { We will discuss in }
\end{aligned}
$$

detail each of the components of the developed model.

Personality is the subject and object of pedagogical education and the educational process as a whole. That is, in the developed model, the participants in the pedagogical educational process - students and teachers - perform basic functions as individuals.

According to the traditional point of view, in pedagogy, personality is understood as "a systemic social quality of the individual, which, as human knowledge develops, is filled with ever deeper content. The existing definitions emphasize that sociality is manifested in the ability of an individual to be a participant in historical progress, to belong to a certain social group, sharing its values and beliefs, to take on various social roles, to influence historical events, to transform society, nature and oneself.

Science - serves to develop the methodological foundations of the pedagogical education process in the model of professional training of future teachers, the development of methodological and technological recommendations. Also, innovations and discoveries in the relevant field of science serve to improve the content of this model.

Society requirements for the professional training of future teachers and the personality of the teacher determine the content and standards of teacher education. In the end, both the personnel trained in the process of teacher education and the field of education they serve should serve the future and development of this society.

Pedagogical education

is the process of teaching future teachers with theoretical, practical and methodological knowledge, which is carried out in pedagogical educational institutions. At the same time, continuous pedagogical education is organized in the process of professional development and independent work.

Professional training involves the development of professional skills, professional competencies and professional psychological training based on teacher education.

In modeling the process of professional training of future teachers, it is necessary to rely on a number of principles that ensure the effectiveness of the modeling process.

1. Compliance of professional pedagogical training with the requirements of the state and society. According to this principle, when modeling the system of teacher training, it is necessary to take into account the needs and requirements of the state and society. At the same time, this standard requirement also helps to develop the basic criteria for the teaching profession in the modeling process.

$2 . \quad$ Continuity, continuity and systematization of teacher education. This principle stipulates that the subjects of teacher education provided for and to be implemented in the model are interconnected, that it should be continuous ("lifelong learning") and should be carried out systematically.

3. Compliance of lifelong professional education with reality.

4. The unity of theory and practice in vocational training.

The model of professional and pedagogical training of young people is implemented in the following areas:

- teaching skills; 
pedagogical

competence;

psychological

training;

Continuous

professional development.

Modeling the process of professional training of future primary school teachers allows you to effectively organize the process of providing the pedagogical process with qualified specialists.

\section{List of used literature:}

1. Khusanov N., Nurullaeva Sh., Kuvatova N., Begimkulova V., Akhmetova K. Pedagogical technology bases for the formation of creative personality in vocational education. International Journal of Advanced Science and Technology Vol. 29, No. 07, (2020), pp. 3362-3365.

2. А. И. Богатырев Теоретические основы педагогического моделирования (сущность и эффективность) [Электронный ресурс] / А.И. Богатырев // Издательский дом «Образование и наука». - Режим доступа: http://www.rusnauka.com/SND/Pedagogic a/2 bogatyrev\%20a.i..doc.htm.

3. Философский словарь / Под ред. И.Т. Фролова. - 5-е изд. - М.: Политиздат, 1987. $-590 \mathrm{c}$

4. Nizomova. M.B. Classification of pedagogical terms in English and Uzbek languages//ИУСЕР. Економика и социум. - №10(77)2020. - № 3 - 6. 178183

5. Н. А. Козырев, О.А. Козырева Педагогическое моделирование как продукт и метод научнопедагогического исследования // Современная педагогика. 2015. №8 [Электронный ресурс]. URL: http://pedagogika.snauka.ru/2015/08/4791 (дата обращения: 07.02.2019).

6. Л. М. Семенова Информационнотехнологический ресурс в имиджелогической подготовке специалиста по связям с общественностью // Вестник
ТГПУ. - 2010. - № 4(94). - С. 98-102.

7. Викулина М.А., Половинкина

В.В. Педагогическое моделирование как продуктивный метод организации и исследования процесса дистанционного образования в вузе.ІІ Ж. Успехи современного естествознания. - 2013. № 3 - C. 109-112.

8. Ш. Нуруллаева "Педагогик махорат" курсидан амалий машғулотларни ташкил этиш технологияси. Карши: Насаф, 2011. 80 б.

9. Ш. Нуруллаева Emotional stability as one of the professional qualities of teachers. Science and world. International scientific journal. № 7(47), 2017. Vol. II. 10. Ш. Нуруллаева , М. Бойматова Замонавий ўқитувчи моделида таълим жараёни ташкилотчиси сифатидаги вазифалар. МЖ.Муғаллим хәм үзликсиз билимлендирий. №3. 2019. 119-122-б. 